\title{
Pelatihan Strategi Menulis Proposal Hibah Kurikulum Merdeka Belajar-Kampus Merdeka
}

\author{
Agus Supriyadi \\ Pendidikan Bahasa Inggris, Universitas Khairun \\ agus_supriyadi@unkhair.ac.id
}

\begin{abstract}
Abstrak
Merdeka Belajar-Kampus Merdeka memberi hak bak belajar tiga semester kepada mahasiswa untuk memilih materi dan perguruan tinggi yang diminati. Tujuan penulisan artikel ini adalah untuk memberikan pelatihan strategi menulis proposl hibah yang baik. Pengabdian dilaksanakan di Program Studi Pendidikan Bahasa Inggris Fakultas Ilmu Pendidikan Universitas Muhammadiyah Maluku Utara. Metode pengabdian yaitu ceramah atau paparan singkat dan diskusi atau tanya jawab mendalam. Hasil yang dicapai adalah terpenuhinya pemahaman cara menulis proposal hibah yang baik.
\end{abstract}

Kata kunci: merdeka belajar, strategi dan proposal hibah.

\section{PENDAHULUAN}

Perkembangan ilmu pengetahuan dan teknologi yang sangat pesat saat ini, telah membawa perubahan yang sangat pesat pula dalam berbagai aspek kehidupan. Pekerjaan dan cara kita bekerja berubah, banyak lapangan pekerjaan hilang, sementara berbagai jenis pekerjaan baru bermunculan. Perubahan ekonomi, sosial, dan budaya juga terjadi dengan laju yang tinggi. Dalam masa yang sangat dinamis ini, perguruan tinggi harus meresponse secara cepat dan tepat. Diperlukan transformasi pembelajaran untuk bisa membekali dan menyiapkan lulusan Pendidikan tinggi agar menjadi generasi yang uggul. Generasi yang tanggap dan siap menghadapi tantangan zamannya, tanpa tercerabut dari akar budaya bangsanya (Nizam, 2020).

Pendidikan Merdeka Belajar merupakan respon terhadap kebutuhan sistem pendidikan pada era Revolusi Industri 4.0. Di era Revolusi Industri 4.0 ini, kebutuhan utama yang ingin dicapai dalam sistem pendidikan atau lebih khusus dalam metode pembelajaran penguasaan siswa terhadap literasi baru, yaitu. literasi data, literasi teknologi dan literasi manusia. Selain itu, dalam sistem Pendidikan Merdeka Belajar tetap mengutamakan juga pendidikan karakter (Yamin \& Syahrir, 2020). "Pendidikan Merdeka Belajar". Konsep ini merupakan respons terhadap kebutuhan sistem pendidikan pada era revolusi industri 4.0. Makarim menyebutkan merdeka belajar merupakan kemerdekaan berfikir. Kemerdekaan berfikir ditentukan oleh guru (Bunga, 2019). Jadi kunci utama menunjang sistem pendidikan yang baru adalah guru. "Tanpa guru melalui proses interpretasi, refleksi dan proses pemikiran secara mandiri, bagaimana menilai kompetensinya, bagaimana menerjemahkan kompetensi dasar, ini menjadi suatu Rencana Pelaksanaan Pembelajaran (RPP) yang baik.

Merdeka belajar menurut Mendikbud adalah kebebasan unit pendidikan (sekolah, guru dan murid) dalam berinovasi maupun belajar dengan mandiri dan 
kreatif. Terdapat empat pokok kebijakan merdeka belajar yang diluncurkan oleh Kemendikbud saat Rapat Koordinasi dengan Kepala Dinas Pendidikan seluruh Indonesia (Kemendikbud, 2019).

Salah satu poin dalam pokok-pokok Kebijakan Merdeka Belajar-Kampus Merdeka (MBKM) yang dikeluarkan Menteri Pendidikan dan Kebudayaan menyebabkan perguruan tinggi harus menata kembali kurikulum perguruan tinggi yang ada di kampus masing-masing. Kurikulum yang sebelumnya berorientasi pada Kerangka Kualifikasi Nasional Indonesia (KKNI), sekarang harus disesuaikan dengan kebijakan MBKM. Penekanannya bukan hanya menyandingkan, menyetarakan, dan mengintegrasikan antara bidang pendidikan dan bidang pelatihan kerja serta pengalaman kerja, tetapi lebih luas lagi ke arah pengalaman real mahasiswa pada program yang akan diambilnya. Tujuan proposal ini adalah menjamin tersedianya dokumen laporan hasil penyusunan kurikulum program studi yang mendukung program MBKM termasuk prosedur konversi dan pengakuan kredit; memperoleh dokumen kurikulum (termasuk capaian pembelajaran yang sesuai dengan SNDikti dan berorientasi KKNI, peta kurikulum, RPS, rubrik, dan portofolio/logbook penilaian); tersedianya dokumen kerja sama kurikulum antara program studi dengan mitra/pihak lain yang berkaitan dalam menunjang pelaksanaan kurikulum MBKM; dan tersedianya dokumen lain (Surat Keputusan Pimpinan perguruan tinggi, dan prosedur operasional baku/panduan) yang menunjang implementasi kurikulum MBKM. Kegiatan pembelajaran yang dapat dilakukan dalam proposal kurikulum MBKM ini adalah pertukaran pelajar, magang/praktik kerja, asistensi mengajar di satuan pendidikan, penelitian/riset, proyek kemanusiaan, kegiatan wirausaha, studi/proyek independen, dan membangun desa/kuliah kerja nyata tematik. Kegiatan monitoring dan evaluasi (monev) program implementasi Pengembangan Program Studi Menerapkan Kerja Sama Kurikulum MBKM dalam perkuliahan di perguruan tinggi dilakukan melalui monev internal dan eksternal. Monev internal dilakukan oleh Pusat Penjaminan Mutu dan Akreditasi, Lembaga Pengembangan Pendidikan dan Penjaminan Mutu (LP3M) Universitas Khairun.

Dengan mengikuti program Merdeka Belajar-Kampus Merdeka (MBKM) ini, perguruan tinggi memberi kesempatan kepada mahasiswa untuk memilih belajar di luar kampus yang mereka sukai. Mahasiswa diberi keleluasaan untuk memilih kegiatan MBKM yang mereka inginkan. Kebijakan ini lahir dari visi misi Presiden Joko Widodo yang akan menciptakan Sumber Daya Manusia (SDM) unggul sebagai upaya mendapatkan generasi masa depan yang berkualitas. Di UMN, program ini akan diterapkan di seluruh program studi yang ada (Prastiwi, 2021).

\section{METODE PELAKSANAAN}

Pelaksanaan pengabdian kepada masyarakat ini saya lakukan secara mandiri untuk tahap awal, yaitu Pelatihan Strategi Jitu Lolos Proposal Hibah MBKM dan akan dilanjutkan oleh Tim Pengabdi MBKM dari Program Studi Pendidikan Bahasa Inggris Fakultas Keguruan dan Ilmu Pendidikan Universitas Khairun yang yelah berkerjasama dengan Universitas Muhammadiyah Maluku Uara selaku perguruan tinggi mitra. Tim MBKM Program Studi akan mensosialisasikan program MBKM dan melakukan pendampingan secara berkala. Untuk mengatasi permasalahan yang 
telah dirumuskan, saya menyusun strategi dan langkah-langkah realistis melalui tahapan kegiatan berikut.

\section{Jadwal Kegiatan}

Pengabdian kepada masyarakat ini dilaksanakan sesuai dengan jadwal sebagai berikut: tanggal pengabdiannya 19 November 2020, waktu pelaksanaannya 09.0011.00 WIT, dan tempat pengabdiannya Fakultas Keguruan dan Ilmu Pendidikan Universitas Muhammadiyah Maluku Utara.

\section{Peserta Kegiatan}

Peserta yang mengikuti kegiatan pelatihan ini adalah Ketua Program Studi Pendidikan Bahasa Inggris dan Ketua Program Studi Pendidikan Guru Sekolah Dasar.

\section{Metode Pelaksanaan}

Untuk mencapai tujuan yang telah dirumuskan sebelumnya, pelaksanan pengabdian masyarakat ini dilakukan dalam beberapa langkah agar dapat memudahkan dalam mengimplementasikannya, yaitu: (a) identifikasi masalah dilakukan sebagai langkah awal untuk merumuskan apa saja yang akan dijadikan bahan untuk perancangan sistem dan materi pelatihan dalam kegiatan pengabdian ini; (b) melakukan koordinasi dengan pimpinan fakultas dan program studi sebagai tempat dilaksanakannya kegiatan, kemudian melakukan proses wawancara dan diskusi dengan pihak program studi untuk identifikasi permasalahan ada dalam perencanaan pembuatan proposal hibah MBKM; (c) penelitian pustaka untuk acuan materi yang digunakan selama kegiatan pengabdian ini.

Untuk merealisasikan program pengabdian ini, ada dua metode utama yang digunakan yaitu: Pertama, metode ceramah atau sosialisasi terbatas. Metode diskusi ini digunakan untuk memberikan informasi dan pemahaman kepada ketua program studi/dosen tentang kebijakan Kemendikbud 2020 yaitu program Merdeka Belajar dan Guru Penggerak. Kedua, metode tanya jawab. Metode diskusi digunakan untuk memberikan kesempatan kepada ketua program studi/dosen yang belum memahami kebijakan MBKM dan langkah-langkahnya. Untuk mencapai tujuan yang telah diprogramkan, metode-metode tersebut di digunakan untuk memberikan pemahaman dan peningkatan kapasitas dosen dan mahasiswa dalam melaksanakan program Merdeka Belajar dan Guru Penggerak.

\section{HASIL DAN PEMBAHASAN}

Program pengabdian ini terdiri dari 1 kegiatan utama yang berkaitan dengan tercipatanya proposal usulan hibah MBKM yang baik. Secara umum, kegiatan ini mendapat respon posiitf dari pimpinan fakultas dan program studi dan dapat berjalan dengan lancar. Hal ini diindikasikan dengan tingginya tingkat konsultasi dan koordinasi program studi. Rincian masing-masing kegiatan, sasaran dan target yang ingin dicapai dijabarkan di bawah ini.

\section{Hasil yang Dicapai}

Hasil yang sudah dicapai dalam pengabdian ini adalah: (a) memberikan pembelajaran dan strategi dalam membuat proposal hibah yang menarik dan 
berkualitas; (b) memberikan gambaran dan penjelasan kepada program studi selaku mitra dalam pengabdian ini bagaimana cara membuat proposal yang baik dan berkualitas, yaitu mengenai kualitas proposal, kesiapan dokumen kerjasama, kesiapan peraturan akademik yang menunjang program MBKM, dan panduan implementasi; (c) memberikan langkah srategis pelaksanaan program setelah proposal dinyatakan lolos seleksi.

\section{SIMPULAN}

Kegiatan pengabdian yang sudah dilakukan yaitu strategi jitu lolos proposal hibah Merdeka Belajar-Kampus Merdeka serta pentingnya implementasi program tersebut. Di dalam pengabdian ini saya dibantu oleh mitra, yaitu Program Studi Pendidikan Bahasa Inggris Fakultas Ilmu Pendidikan Universitas Muhammadiyah Maluku Utara. Agar pelatihan ini memiliki dampak yang signifikan, maka bimbingan dan pendampingan terus dilakukan secara berkala. Konsep merdeka belajar-kampus merdeka merupakan tawaran dalam merekonstruksi sistem pendidikan nasional. Perubahan kurikulum secara berkala adalah suatu keniscayaan yang harus dilakukan untuk memperbaiki dan meningkatkan mutu pendidikan. Penataan kembali dan tata kelola sistem pendidikan perlu disesuaikan dengan perkembangan ilmu pengetahuan dan teknologi yang mutahir dan terbarukan. Dengan demikian, marwah pendidikan di Indonesia dapat dicapai secara maksimal dan kembali kepada khitohnya, yaitu pendidikan untuk memanusiakan manusia.

\section{UCAPAN TERIMA KASIH}

Saya berterima kasih kepada semua pihak yang telah membantu terselenggaranya pelatihan ini terutama kepada Ibu Roswita M. Aboe, S.Pd., M.A yang telah menjembatani kerjasama dengan mitra.

\section{DAFTAR PUSTAKA}

Bunga, H. (2019). Nadiem Makarim: Merdeka Belajar adalah Kemerdekaan Berpikir. Persada, S. (Ed.) Tempo.co [HTM file]. Tersedia: https://nasional.tempo.co/read/1283493/nadiem-makarim-merdeka-belajaradalah-kemerdekaan-berpikir/full\&view=ok

Kementrian Pendidikan dan Kebudayaan. (2019). Merdeka Belajar. Materi Rapat Koordinasi dengan Kepala Dinas Pendidikan Seluruh Indonesia, 11 Desember 2019. Jakarta: Kemendikbud.

Nizam. (2020). Buku Panduan Merdeka Belajar-Kampus Merdeka. Jakarta: Dirjendikti Kemdikbud.

Prastiwi, M. (2021). Tingkatkan Kompetensi Mahasiswa, UMN Terapkan Kurikulum Kampus Merdeka. Kasih, A. P. (Ed.). Kompas.com [HTM file]. Tersedia: $\quad$ https://www.kompas.com/edu/read/2021/03/11/183000871/ tingkatkan-kompetensi-mahasiswa-umn-terapkan-kurikulum-kampusmerdeka.

Yamin, M., \& Syahril, S. (2020). Pembangunan Pendidikan Merdeka Belajar (Telaah Metode Pembelajaran). Jurnal Ilmiah Mandala Education, 6(1), 126136. 